\title{
Varierende tilgang til barneradiologisk kompetanse
}

\author{
Tilgangen til barneradiologisk kompetanse varierer betydelig ved landets røntgen- og barneavdelinger. \\ Manglende kompetanse kan medføre alvorlig feildiagnostikk og unødvendige undersøkelser. Det er behov \\ for en systematisert kartlegging og styrking av det barneradiologiske tilbudet i Norge.
}

Nytten av en radiologisk tjeneste spesielt tilpasset barn ble nylig tydeliggjort $\mathrm{i}$ en studie fra USA, der over en tredel av primærdiagnosene stilt av generell radiolog, avvek fra diagnose stilt ved sekundærgranskning av barneradiolog (1). Halvparten av avvikene ble betegnet som alvorlige, for eksempel kraniefrakturer, intrakraniale blødninger, appendisitt, kolitt, hepatitt, kolecystitt, fri luft $\mathrm{i}$ abdomen og pneumothorax.

Funnene er ikke overraskende sett i lys av den enorme utviklingen radiologifaget har gjennomgått de siste tiårene, med innføring av nye modaliteter, bildeveiledede prosedyrer og behandlinger. For å kunne tilby tidsriktig og kunnskapsbasert diagnostikk er det derfor etablert uformelle, radiologiske subspesialiteter. Norsk radiologisk forening har per i dag sju underforeninger, for nevroradiologi, muskel- og skjelettradiologi, abdominal radiologi, intervensjon, radiologisk brystdiagnostikk, thorax og pediatrisk radiologi. Generellradiologen spiller fortsatt en viktig rolle ved mindre avdelinger, men det kan ikke forventes at han greier å holde seg tilstrekkelig oppdatert innen alle subspesialiteter - spesielt ikke innen barneradiologi, som skiller seg betydelig fra voksendiagnostikk med tanke på sykdomspanorama, indikasjonsstillinger, valg av modalitet og teknikk og tolking av funn $(2,3)$. I en fersk studie som inkluderte 520 traume-CT-undersøkelser av barn, viste forfatterne blant annet at stråledosen var betydelig lavere for undersøkelser utført ved dedikerte barnesykehus enn dem utført ved «community hospitals» (4). En del av forklaringen, mente forfatterne, var mangelfull barneradiologisk kompetanse.

En vellykket barneradiologisk undersøkelse krever i tillegg inngående kunnskap om barns utviklings- og funksjonsnivå og evne til å etablere en trygg atmosfære i undersøkelsessituasjonen. Uten slik kompetanse kan en ultralydundersøkelse lett bli mangelfull, mens røntgen- og CT-undersøkelser oftere må tas opp igjen på grunn av bevegelsesartefakter. Når det gjelder MRundersøkelser, er kjennskap til trygghetsskapende tiltak, som «mock MRI», viktig for å redusere behovet for narkose (5).

\section{Kompetanse ved sykehus}

Vi utførte i løpet av 2013 en spørreundersøkelse blant landets radiologer (6). Spørreskjemaet ble utarbeidet i samarbeid med Legeforskningsinstituttet og Norsk forening for pediatrisk radiologi ved styret. Det inneholdt 25 spørsmål om blant annet antall stillinger (radiologer, radiografer) dedikert barn, antall undersøkelser av barn i løpet av 2011 og tilrettelegging av de ulike undersøkelsene. Spørreskjemaet ble sendt til alle medlemmene i Norsk radiologisk forening per mai $2013(\mathrm{n}=700)$ via e-post. Målet

\section{«Kun en firedel av undersøkelsene utført i vanlig arbeidstid ble gjort av barneradio- grafer og -radiologer»}

var å motta minst ett representativt svar fra hvert sykehus/hver radiologiske avdeling, og vi utførte en telefonspørring til de avdelingene som ikke var representert i svarene per 1.9. 2013.

Undersøkelsen viste blant annet at om lag $9 \%$ av alle undersøkelser som ble utført i 2011, involverte barn opptil 14 år, og at kun en firedel av undersøkelsene utført i vanlig arbeidstid ble gjort av barneradiografer og -radiologer. Barneradiologisk kompetanse på kveld/natt og i helger var tilgjengelig ved to av de 42 statlige sykehusavdelingene som besvarte spørreundersøkelsen, nemlig Oslo universitetssykehus, Ullevål og Rikshospitalet (6). Ved de øvrige sykehusene ble barneundersøkelser på vakt stort sett utført av radiologer uten spesiell kompetanse innen barneradiologi.

37 av 42 sykehusavdelinger hadde ikke spesielt tilrettelagte undersøkelsesrom og -utstyr for barn. Av de statlige sykehusene oppga 15 at de til en viss grad var tilrettelagte, med leker og bilder for barn, mens 19 sykehus var lite tilrettelagte. De hadde leker på venteværelset, men ikke noe mer.

\section{Grunn til bekymring?}

Sett i lys av nyere litteratur og egen erfaring gir funnene fra spørreundersøkelsen grunn til bekymring. En kvalitetskontroll ved Haukeland universitetssykehus høsten 2012 (upubliserte data) viste at $15 \%$ av diagnosene som ble stilt på vakt i løpet av en åtte ukers periode, avvek fra endelig diagnose gitt av barneradiolog én eller flere dager $i$ etterkant. Undersøkelsen indikerte at 7-8 barn per år enten ville måtte gjennomgå en unødvendig operativ behandling, eller at operasjon ble forsinket, med fare for alvorlige komplikasjoner. Vår bekymring deles av hele det europeiske fagmiljøet, og det pågår nå et omfattende arbeid - i regi av European Society for Paediatric Radiology - for å etablere et adekvat kurstilbud og utarbeide retningslinjer og anbefalinger for undersøkelser av barn (7). Det vil også utarbeides en type godkjenning/«European Diploma» for bildediagnostiske undersøkelser og bildeveiledede behandlinger av barn.

\section{Hva kan gjøres?}

Undersøkelser av barn utføres ved de fleste radiologiske avdelinger. For å sikre et tilstrekkelig godt tilbud kan avdelinger med mer enn 6-7 overleger overlate de fleste barneundersøkelsene, dvs. opp mot $10 \%$ av alle undersøkelsene (8), til én av overlegene ved avdelingen. Dette vil gi en rimelig arbeidsdeling, idet undersøkelser av barn kan være både tidkrevende og til tider utfordrende. Vedkommende radiolog vil således kunne tilegne seg tilstrekkelig praktisk kompetanse om de vanligste tilstandene, som utredning av urinveisinfeksjon, pneumoni, artritt, hofteleddsdysplasi etc. og ha et særlig ansvar for å holde seg, og resten av kollegiet, faglig oppdatert. I en vaktsituasjon, og ved mer komplekse problemstillinger, kan bildediagnostikken utføres i tett samarbeid med nærmeste barneradiolog, dvs. ved regionens universitetsklinikk. Et slikt samarbeid er spesielt viktig ved utredning av malignitet, fysiske mishandlingsskader og skjelettdysplasier/metabolske sykdommer.

Et annet tiltak kunne være å inkludere barneradiologisk tjeneste i spesialiteten radiologi. I dag kreves kun én ukes teorikurs i barneradiologi for å bli godkjent spesialist. Dette betyr i praksis at et radiologisk vaktteam ikke nødvendigvis innehar barneradiologisk kompetanse, unntatt Oslo universitetssykehus.

Spørreundersøkelsen vi har gjennomført (6), viste at tilbudet i barneradiologi varierer betydelig mellom landsdelene og mellom sykehus. Studier har vist at manglende barneradiologisk kompetanse kan medføre alvorlig feildiagnostikk. Det er bekymringsfullt og rimer ikke med de intensjonene som 
er nedfelt i Forskrift om barns opphold $i$ helseinstitusjon $(9,10)$. Forskriften inneholder bestemmelser om barns rettigheter og sykehusenes plikter i forbindelse med sykehusopphold, og sier blant annet at avdelinger der barn legges inn, skal utstyres etter barns behov.

Vi mener derfor at våre funn bør følges opp av en systematisert og robust kartlegging av det barneradiologiske tilbudet i Norge, i regi av de ansvarlige myndighetene.

Karen Rosendahl

karen.rosendahl@helse-bergen.no Aud Feed

Karen Rosendahl (f. 1955) er spesialist i radiologi, med spesialkompetanse i barneradiologi og muskel- og skjelettsykdommer hos barn. Hun er overlege ved Radiologisk avdeling, Seksjon for barn, Haukeland universitetssykehus, professor II ved Universitet i Bergen, medlem av styret i European Society for Paediatric Radiology (ESPR) og europeisk president for
International Pediatric Radiology (IPR) Chicago 2016.

Forfatter har fylt ut ICMJE-skjemaet og oppgir ingen interessekonflikter.

Aud Feed (f. 1986) var medisinstudent ved Universitetet i Bergen frem til juni 2015 og er turnuslege ved Stavanger universitetssykehus fra høsten 2015. Hun har skrevet særoppgave på studiet om barneradiologitilbudet i Norge. Forfatter har fylt ut ICMJE-skjemaet og oppgir ingen interessekonflikter.

\section{Litteratur}

1. Eakins C, Ellis WD, Pruthi S et al. Second opinion interpretations by specialty radiologists at a pediatric hospital: rate of disagreement and clinical implications. AJR Am J Roentgenol 2012; 199 916-20.

2. Müller Ording LS. Establishment of normative MR standards for the paediatric skeleton to better outline pathology. Focused on juvenile idiopathic arthritis. A dissertation for the degree of philosophiae doctor. Doktoravhandling. Tromsø: Universitetet i Troms $\varnothing$, Det medisinske fakultet, 2012

3. Rosendahl K. Acta Radiologica: Special Pediatric Issue 2013. Acta Radiol 2013; 54: 981
4. Agarwal S, Jokerst C, Siegel MJ et al. Pediatric emergency CT scans at a children's hospital and at community hospitals: radiation technical factors are an important source of radiation exposure. AJR Am J Roentgenol 2015; 205: 409-13.

5. Carter AJ, Greer ML, Gray SE et al. Mock MRI: reducing the need for anaesthesia in children. Pediatr Radiol 2010; 40: 1368-74.

6. Feed A. Barneradiologi i Norge per 2013. Bergen Det medisinsk-odontologiske fakultet, Universitetet i Bergen. https://bora.uib.no/handle/1956/ 10138 (4.8. 2015)

7. European Society for Paediatric Radiology. www.espr.org (4.8. 2015).

8. Orderud W. Barneradiologi i Norge. Oslo: Universitetet i Oslo, 1991.

9. Forskrift om barns opphold i helseinstitusjon https://regjeringen.no/no/dokumenter/ forskrift-om-barns-opphold-i-helseinstit/id91998 (4.8. 2015)

10. Nortvedt L, Kase BF. Forskrift om barn i sykehus. En spørreundersøkelse om barns rettigheter ved 14 norske sykehus. Tidsskr Nor Lægeforen 1997; 117: $4102-5$

Mottatt 26.6. 2015, første revisjon innsendt 15.7. 2015, godkjent 27.7. 2015. Redaktør: Hanne Støre valeur.

Publisert først på nett. 